\title{
In vitro digestibility and fermentability of fructo-oligosaccharides produced by Aspergillus ibericus
}

\author{
C. Nobre ${ }^{\mathrm{a}, *}$, S.C. Sousa ${ }^{\mathrm{b}}$, S.P. Silva ${ }^{\mathrm{c}}$, A.C. Pinheiro ${ }^{\mathrm{a}, \mathrm{d}}$, E. Coelho ${ }^{\mathrm{c}}$, A.A. Vicente ${ }^{\mathrm{a}}$, A.M.P. Gomes ${ }^{\mathrm{b}}$, \\ M.A. Coimbra ${ }^{c}$, J.A. Teixeira ${ }^{a}$, L.R. Rodrigues ${ }^{a}$ \\ ${ }^{\text {a }}$ Centre of Biological Engineering, University of Minho, Campus de Gualtar, 4710-057 Braga, Portugal \\ ${ }^{\mathrm{b}}$ Universidade Católica Portuguesa, CBQF - Centro de Biotecnologia e Química Fina - Laboratório Associado, Escola Superior de Biotecnologia, Rua Arquiteto Lobão Vital, \\ 172, 4200-374 Porto, Portugal \\ ${ }^{c}$ QOPNA, Departamento de Química, Universidade de Aveiro, 3810-193 Aveiro, Portugal \\ ${ }^{\mathrm{d}}$ Instituto de Biologia Experimental e Tecnológica, Avenida da República, Quinta-do-Marquês, Estação Agronómica Nacional, Apartado 12, 2781-901 Oeiras, Portugal
}

A R T I C L E I N F O

\section{Keywords:}

Fructo-oligosaccharides

Aspergillus

Prebiotics

Probiotics

Glycosidic linkage analysis

NeoFOS

\begin{abstract}
A B S T R A C T
The bifidogenic potential of fructo-oligosaccharides (FOS) produced by a newly isolated strain - Aspergillus ibericus was studied. Their activity was compared to FOS produced by Aureobasidium pullulans and to a nonmicrobial commercial FOS sample (Raftilose ${ }^{\oplus}$ P95). FOS fermentability by a number of probiotic bacteria and their hydrolytic resistance to the simulated harsh conditions of the digestive system was evaluated. Aspergillus ibericus FOS sample effectively promoted probiotic bacteria growth. Overall, microbial-derived FOS promoted greater cellular growth compared to the commercial sample. FOS fermentation was both substrate and strain specific. The FOS structural differences identified may explain their distinct assimilation by the probiotics. [Fru $(2 \rightarrow 6) \mathrm{Glc}$ ] (possibly blastose) and a reducing trisaccharide (possibly [Fru( $\beta 2 \rightarrow 6) \mathrm{Glc}(\alpha 1 \leftrightarrow \beta 2)$ Fru], neokestose) were only found in microbial-derived FOS samples, while Raftilose ${ }^{\star}$ P95 was richer in inulobiose/inulotriose. 1Kestose and nystose were only slightly hydrolyzed in the presence of gastric and intestinal fluid. FOS synthesized by Aspergillus exhibited great potential as food ingredients with likely prebiotic features.
\end{abstract}

\section{Introduction}

Human nutrition and health are intrinsically related with the efficiency of the gastrointestinal system. Through the active modulation of the colonic microbiota with a regular daily ingestion of prebiotics, such as fructo-oligosaccharides (FOS), it has been possible to reduce a great number of pathophysiological disorders and associated chronic diseases such as irritable bowel syndrome (Chen et al., 2017), osteoporosis (Bryk et al., 2015), obesity (Whelan, Efthymiou, Judd, Preedy, \& Taylor, 2006), metabolic syndrome and dyslipidaemia (Mallappa et al., 2012), immune system regulation (Frei, Akdis, \& O'Mahony, 2015) and colon cancer (Pool-Zobel, 2005). FOS have been extensively used as prebiotics in diabetic, dietetic and infant foods (Al-Sheraji et al., 2013; Padma \& Prabhasankar, 2014; Panesar, Kumari, \& Panesar, 2013). Their incorporation in food greatly improves the technological and nutritional properties of the final products, namely the organoleptic characteristics; product shelf-life, reduction of browning due to Maillard reactions, low energy ingredient as fat replacer and enable fiber incorporation within liquid foods (Franck, 2002).
Currently, the FOS commercially available are mainly obtained from inulin hydrolyzed or by enzymatic transformation of sucrose using microbial enzyme fructosyltransferases (Nobre, Teixeira, \& Rodrigues, 2015). Fungi, belonging to the Aspergillus, Penicillium and Aureobasidium genera, are among the most studied microorganisms used for the production of FOS (Maiorano, Piccoli, Da Silva, \& De Andrade Rodrigues, 2008). The attainment of FOS yields higher than $55-60 \%$ is still a challenge due to enzyme inhibition by the products released during FOS synthesis (Sangeetha, Ramesh, \& Prapulla, 2005). Consequently, several researchers continue to pursue new and optimized conditions towards higher FOS production yields such as the use of whole cells, instead of purified enzymes (Castro, Nobre, Duprez, De Weireld, \& Hantson, 2017; Dominguez et al., 2012; Nascimento, Nobre, Cavalcanti, Teixeira, \& Porto, 2016; Nobre et al., 2016) and the use of new isolated strains such as the Aspergillus ibericus MUM 03.49, an isolate from Portuguese wine grapes (Nobre et al., 2018), duly characterized, with great potential for FOS production. As a result, current studies are not only focused on the physicochemical characteristics of the new FOS produced by these microorganisms, but also on their prebiotic index.

\footnotetext{
* Corresponding author.

E-mail addresses: clarissenobre@deb.uminho.pt, clarissenobre@gmail.com (C. Nobre).
} 
To classify a food ingredient as prebiotic, a number of criteria must be fulfilled, namely resistance to gastric juice, hydrolysis by salivary, pancreatic and brush border enzymes; and selective fermentation ability by the intestinal microbiota (Gibson et al., 2010). Therefore, oligosaccharides produced by new isolated strains must be submitted to several simulated digestion steps to determine the effective amount of carbohydrates that can reach the large intestine and be further metabolized by the probiotic bacteria.

Lactobacillus and Bifidobacterium probiotic strains are among the indigenous gut bacteria that selectively grow in the presence of prebiotic FOS. Some of these bacteria have been used as probiotic cultures, mainly in yogurts and fermented milks (Mattila-Sandholm et al., 2002). For this reason, their ability to ferment specific carbohydrates provides useful information about the prebiotic features of the metabolized carbohydrates. Although the dietary intake of specific carbohydrates has proved to exert an important influence on the resultant composition of the human gut microbiome, it is not clear which prebiotic carbohydrates are the most suitable substrates for a selective growth of specific strains (Chung et al., 2016; Huebner, Wehling, \& Hutkins, 2007). In vitro tests have been conducted to evaluate the functional activity of different prebiotics, including FOS (Kaplan \& Hutkins, 2000; Rada et al., 2008; Su, Henriksson, \& Mitchell, 2007).

This work aims at evaluating and comparing the potential prebioticlike activity of three FOS samples obtained from different sources: FOS produced by a new isolated strain of $A$. ibericus, FOS produced by Aureobasidium pullulans and the commercially available Raftilose $\mathrm{P} 95$. The oligosaccharides were characterized by sugars and linkage analysis using different chromatographic techniques and comparison with available standards. The glycosidic linkages of the oligosaccharide sugar residues were identified by methylation analysis and further, the oligosaccharides structure was analyzed by gas chromatographyquadrupole mass spectrometry (GC-qMS). The ability of several Bifidobacterium and Lactobacillus strains to ferment the different FOS samples was determined. The resistance of each sample to the in vitro conditions simulating the gastrointestinal system was also evaluated.

\section{Material and methods}

\subsection{Potential prebiotic carbohydrates}

FOS samples from three different sources were characterized by analysis of their glycosidic linkage (Section 2.2) and evaluated for their potential prebiotic activity, namely in vitro utilization by probiotic bacteria (Section 2.3) and in vitro digestion using a gastrointestinal

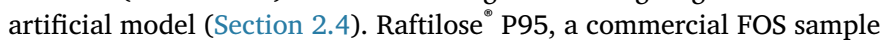
from Beneo-Orafti Group (Oreye, Belgium), was tested and the results were compared with two FOS samples produced in our laboratory by $A$. pullulans CCY 27-1-94 (Culture Collection of Yeasts, Bratislava, Slovakia) and A. ibericus MUM 03.49 (Culture collection of Micoteca da Universidade do Minho (MUM), Braga, Portugal). FOS samples were produced by fermentation using the whole cells of each microorganism (A. pullulans production conditions reported in Nobre et al., 2016; A. ibericus production conditions reported in Nobre et al. 2018) and purified using an activated charcoal column (as described in Nobre, Teixeira, \& Rodrigues, 2012).

\subsection{Glycosidic linkage analysis}

The glycosidic linkages were identified by methylation analysis, as described in Coelho, Rocha, Moreira, Domingues, \& Coimbra (2016). The oligosaccharides were methylated using $\mathrm{CH}_{3} \mathrm{I}$, hydrolysed (TFA $2 \mathrm{M})$ and the resultant monosaccharides were reduced $\left(\mathrm{NaBD}_{4}\right)$ and acetylated. The partially methylated alditol acetates (PMAAs) obtained were analyzed by gas chromatography-mass spectrometry (GC-qMS) on a Shimadzu GCMS-QP2010 Ultra. The GC was equipped with a DB-1 (J \& W Scientific, Folsom, CA, USA) capillary column (30 m length,
$0.25 \mathrm{~mm}$ of internal diameter and $0.10 \mu \mathrm{m}$ of film thickness).

\subsection{Carbohydrates identification and quantification by GC-qMS}

Carbohydrates contained in the three FOS samples were analyzed using a modified version of the method of Simões, Nunes, Domingues, \& Coimbra (2011). Sucrose, trehalose, kojibiose, laminaribiose, nigerose, maltose, isomaltose, sophorose, cellobiose, gentiobiose, 1-kestose, melezitose, panose, isomaltotriose, nigerotriose, and cellotriose were used as standards. Samples (1-2 mg) and 2-deoxyglucose as internal standard (20-200 $\mu \mathrm{L}$ of $\left.1 \mathrm{mg} \cdot \mathrm{L}^{-1}\right)$ were derivatized, in duplicate, by adding $200 \mu \mathrm{L}$ of a sodium borohydride solution $\left(15 \%(\mathrm{~m} / \mathrm{v})\right.$ in $\left.\mathrm{NH}_{3} 3 \mathrm{M}\right)$ and incubated at $30^{\circ} \mathrm{C}$ for $60 \mathrm{~min}$. Afterwards, the excess of the reducing agent was destroyed by the addition of glacial acetic acid $(0.1 \mathrm{~mL})$. The acetylation of the alditols was performed by adding 1-methylimidazole $(0.45 \mathrm{~mL})$ and acetic anhydride $(3 \mathrm{~mL})$ and allowed to react for $30 \mathrm{~min}$, at $30^{\circ} \mathrm{C}$. This solution was treated with water $(3 \mathrm{~mL})$ to decompose the excess of acetic anhydride, and the alditol acetates were extracted with dichloromethane $(5 \mathrm{~mL})$. The dichloromethane phase was washed two times with water $(3 \mathrm{~mL})$ and evaporated to dryness. The alditol acetates were dissolved in anhydrous acetone $(70-500 \mu \mathrm{L})$ and analyzed by GC-qMS with the same column used for the linkage analysis. The samples were injected in split mode (split ratio of 33), with the injector operating at $250^{\circ} \mathrm{C}$, using the following temperature program: initial temperature of $140^{\circ} \mathrm{C}$ followed by a linear increase of $5^{\circ} \mathrm{C} \cdot \mathrm{min}^{-1}$ until $180^{\circ} \mathrm{C}$, and standing $1 \mathrm{~min}$ at this temperature, followed by a linear increase of $5{ }^{\circ} \mathrm{C} \cdot \mathrm{min}^{-1}$ until $250^{\circ} \mathrm{C}$, maintaining this temperature $10 \mathrm{~min}$, with further linear increase of $10^{\circ} \mathrm{C} \cdot \mathrm{min}^{-1}$ until $325^{\circ} \mathrm{C}$, standing $3 \mathrm{~min}$ at this temperature. Linear velocity of the carrier gas (He) was set at $35 \mathrm{~cm} \cdot \mathrm{s}^{-1}$ at $200{ }^{\circ} \mathrm{C}$, with a solvent delay of $2 \mathrm{~min}$. MS scans were performed for GC-qMS between 33 and $700 \mathrm{~m} / \mathrm{z}$ at $70 \mathrm{eV}$ ionization energy.

\subsection{Microorganisms}

Fourteen probiotic strains were tested in their response to the different FOS samples to detect possible growth behavior differences among different genera, species and strains (Table 1). The Lactobacillus and Bifidobacterium strains used herein were specifically selected given their potential probiotic properties.

Lactobacillus and Bifidobacterium cultures were maintained at $-80^{\circ} \mathrm{C}$ in a $30 \%(\mathrm{v} / \mathrm{v})$ glycerol solution. For the prebiotic activity assays, frozen cultures were re-activated in de Man-Rogosa-Sharpe (MRS; Biokar Diagnostics, France) broth, followed by overnight incubation at $37^{\circ} \mathrm{C}$. For the particular case of Bifidobacterium strains, MRS was supplemented with filter-sterilized $0.5 \mathrm{~g} \cdot \mathrm{L}^{-1}$ of L-cysteine $\cdot \mathrm{HCl}$ (Merck, Germany) to lower the redox potential, and these strains were incubated in a plastic anaerobic jar with a $\mathrm{GasPak}^{\mathrm{TM}} \mathrm{EZ}$ anaerobe container system sachet (an atmosphere generating system from BD, USA) in order to guarantee anaerobic conditions. Pre-cultures were also prepared according to the aforementioned conditions.

\subsection{In vitro utilization of carbon sources by probiotic bacteria}

MRS broth with the carbon source replaced by the different oligosaccharide samples was used to assess their prebiotic-like potential. The MRS broth without carbon source was autoclaved at $121^{\circ} \mathrm{C}$ for $15 \mathrm{~min}$ and it was composed of $10 \mathrm{~g} \cdot \mathrm{L}^{-1}$ of peptone, $10 \mathrm{~g} \cdot \mathrm{L}^{-1}$ of meat extract, $5 \mathrm{~g} \cdot \mathrm{L}^{-1}$ of yeast extract, $2 \mathrm{~g} \cdot \mathrm{L}^{-1}$ of $\mathrm{K}_{2} \mathrm{HPO}_{4}, 1.08 \mathrm{~g} \cdot \mathrm{L}^{-1}$ of Tween 80 , $5 \mathrm{~g} \cdot \mathrm{L}^{-1}$ of $\mathrm{C}_{2} \mathrm{H}_{3} \mathrm{NaO}_{2}, 2 \mathrm{~g} \cdot \mathrm{L}^{-1}$ of ammonium citrate tribasic, $0.2 \mathrm{~g} \cdot \mathrm{L}^{-1}$ of $\mathrm{MgSO}_{4}$ and $0.05 \mathrm{~g} \cdot \mathrm{L}^{-1}$ of $\mathrm{MnSO}_{4}$. Solutions of glucose, Raftilose $\mathrm{P} 95$, FOS from A. pullulans or FOS from A. ibericus were prepared and filtersterilized through $0.2 \mu \mathrm{m}$ filters. Each of these solutions was then added, separately to the MRS broth to achieve a final concentration of $2 \%(\mathrm{w} / \mathrm{v})$ and, filter-sterilized deionized water was used as a negative control. 
Table 1

Probiotic strains tested to assess FOS samples as carbon source.

\begin{tabular}{|c|c|c|c|}
\hline Genus & Species & Strain & Supplier \\
\hline \multirow[t]{10}{*}{ Lactobacillus } & acidophillus & $\mathrm{Ki}$ & CSK, Ede, the Netherlands \\
\hline & & LAFTI $^{*}$ L10 & DSM Food Specialties, Moorebank, Australia \\
\hline & casei & ssp. paracasei LAFTI $^{\circ}$ L26 & DSM Food Specialties, Moorebank, Australia \\
\hline & & 01 & Chr. Hansen, Hørsholm, Denmark \\
\hline & & 431 & Chr. Hansen, Hørsholm, Denmark \\
\hline & plantarum & $299 v$ & PROBI AB, Lund, Sweden \\
\hline & & D36 & Isolated from persimmon; ESB collection \\
\hline & rhamnosus & R11 & Lallemand, Montreal, Canada \\
\hline & & 20021 & DSMZ, Braunschweig, Germany \\
\hline & brevis & D24 & Isolated from persimmon; ESB collection \\
\hline \multirow[t]{4}{*}{ Bifidobacterium } & animalis & ssp. lactis $\mathrm{BB}-12^{\circ}$ & Chr. Hansen, Hørsholm, Denmark \\
\hline & & ssp. lactis BLC & DSM Food Specialties, Moorebank, Australia \\
\hline & & Bo & CSK, Ede, Netherlands \\
\hline & & ssp. lactis $\mathrm{B} 94^{\circ}$ & DSM Food Specialties, Moorebank, Australia \\
\hline
\end{tabular}

Assays were performed by adding $2 \%(\mathrm{v} / \mathrm{v})$ of each probiotic strain (Table 1), pre-grown overnight, to the MRS broth containing the different carbon sources. These inoculated media were transferred (300 or $250 \mu \mathrm{L}$, in case of Lactobacillus or Bifidobacterium strains, respectively) to a 96-well microplate. The microplate was incubated at $37^{\circ} \mathrm{C}$ for $24 \mathrm{~h}$. The optical density at $660 \mathrm{~nm}$ of each well was recorded every hour, using a FLUOstar OPTIMA) microplate reader (BMG LABTECH, Germany). For Bifidobacterium strains, as previously mentioned, MRS was supplemented with filter-sterilized $0.5 \mathrm{~g} \cdot \mathrm{L}^{-1}$ of L-cysteine $\mathrm{HCl}$ and the wells were covered with $50 \mu \mathrm{L}$ of autoclave-sterilized liquid paraffin to avoid oxygen contact. All assays were carried out in triplicate.

Peptone, ammonium citrate tribasic and $\mathrm{MnSO}_{4}$ were obtained from Sigma-Aldrich (France), yeast extract was obtained from Biokar Diagnostics (France) and meat extract, $\mathrm{K}_{2} \mathrm{HPO}_{4}$, Tween $80, \mathrm{C}_{2} \mathrm{H}_{3} \mathrm{NaO}_{2}$, $\mathrm{MgSO}_{4}$ and liquid paraffin were obtained from Merck.

\subsection{In vitro digestion of FOS samples}

In vitro digestion was performed as described elsewhere (Minekus et al., 2014). Briefly, $5 \mathrm{~mL}$ of each carbohydrate sample under study, at a concentration of $12.5 \%$ in total sugars, was prepared and subsequently exposed to conditions simulating the environment of the mouth, stomach and small intestine.

The simulation of the oral phase consisted in the addition of simulated salivary fluid (SSF) $\left(\mathrm{KCl} 15.1 \mathrm{mmol} \cdot \mathrm{L}^{-1}, \mathrm{KH}_{2} \mathrm{PO}_{4} 3.7 \mathrm{mmol} \cdot \mathrm{L}^{-1}\right.$, $\mathrm{NaHCO}_{3} 13.6 \mathrm{mmol} \cdot \mathrm{L}-1, \quad \mathrm{MgCl}_{2} \cdot\left(\mathrm{H}_{2} \mathrm{O}\right)_{6} 0.15 \mathrm{mmol} \cdot \mathrm{L}^{-1},\left(\mathrm{NH}_{4}\right)_{2} \cdot \mathrm{CO}_{3}$ $0.06 \mathrm{mmol} \cdot \mathrm{L}^{-1}$, and $\mathrm{HCl} 1.1 \mathrm{mmol} \cdot \mathrm{L}^{-1}$ ), $\mathrm{CaCl}_{2} \cdot\left(\mathrm{H}_{2} \mathrm{O}\right)_{2}$ (to obtain $1.5 \mathrm{mmol} \cdot \mathrm{L}^{-1}$ in the fluid) and purified water (necessary volume to dilute the SSF stock solution). The sample was incubated for $2 \mathrm{~min}$ at $37^{\circ} \mathrm{C}$. Note that alpha-amylase was not used since starch was absent in the samples evaluated. No hydrolysis was found in a preliminary test conducted with alpha-amylase and FOS (data not shown).

The gastric secretion (simulation of the passage through the stomach) consisted of porcine pepsin solution $\left(2000 \mathrm{U} \cdot \mathrm{mL}^{-1}\right.$ in the final sample), simulated gastric fluid (SGF) ( $\mathrm{KCl} 6.9 \mathrm{mmol} \cdot \mathrm{L}^{-1}, \mathrm{KH}_{2} \mathrm{PO}_{4}$ $0.9 \mathrm{mmol} \cdot \mathrm{L}^{-1}, \quad \mathrm{NaHCO}_{3} \quad 25 \mathrm{mmol} \cdot \mathrm{L}^{-1}, \quad \mathrm{NaCl} \quad 47.2 \mathrm{mmol} \cdot \mathrm{L}^{-1}$, $\mathrm{MgCl}_{2} \cdot\left(\mathrm{H}_{2} \mathrm{O}\right)_{6} \quad 0.1 \mathrm{mmol} \cdot \mathrm{L}^{-1}, \quad\left(\mathrm{NH}_{4}\right)_{2} \cdot \mathrm{CO}_{3} \quad 0.5 \mathrm{mmol} \cdot \mathrm{L}^{-1}$ and $\mathrm{HCl}$ $15.6 \mathrm{mmol} \cdot \mathrm{L}^{-1}$ ), $\mathrm{CaCl}_{2} \cdot\left(\mathrm{H}_{2} \mathrm{O}\right)_{2}$ (to obtain $0.15 \mathrm{mmol} \cdot \mathrm{L}^{-1}$ in the fluid), $\mathrm{HCl}$ to adjust $\mathrm{pH}$ to 3.0 and purified water (volume needed to dilute the SGF stock solution). The samples were incubated in a shaking bath at $37^{\circ} \mathrm{C}$ for $2 \mathrm{~h}$.

The intestinal phase was simulated by adding simulated intestinal fluid (SIF) (KCl $6.8 \mathrm{mmol} \cdot \mathrm{L}^{-1}, \quad \mathrm{KH}_{2} \mathrm{PO}_{4} \quad 0.8 \mathrm{mmol} \cdot \mathrm{L}^{-1}, \quad \mathrm{NaHCO}_{3}$ $85 \mathrm{mmol} \cdot \mathrm{L}^{-1}$, NaCl $38.4 \mathrm{mmol} \cdot \mathrm{L}^{-1}, \mathrm{MgCl}_{2} \cdot\left(\mathrm{H}_{2} \mathrm{O}\right)_{6} 0.33 \mathrm{mmol} \cdot \mathrm{L}^{-1}$, and $\left.\mathrm{HCl} 8.4 \mathrm{mmol} \cdot \mathrm{L}^{-1}\right), \mathrm{CaCl}_{2} \cdot\left(\mathrm{H}_{2} \mathrm{O}\right)_{2}$ (to obtain $0.6 \mathrm{mmol} \cdot \mathrm{L}^{-1}$ in the fluid), pancreatin suspension in SIF (based on trypsin activity of $100 \mathrm{U} \cdot \mathrm{mL}^{-1}$ in the final sample), bile solution in SIF (to obtain $10 \mathrm{mmol} \cdot \mathrm{L}^{-1}$ in the final sample), $\mathrm{NaOH}$ (volume necessary to adjust the $\mathrm{pH}$ to 7.0 ) and purified water (volume needed to dilute the stock solution of SIF). The samples were incubated for $2 \mathrm{~h}$ at $37^{\circ} \mathrm{C}$.

Note that all the electrolyte solutions (SSF, SGF and SIF) were prepared $1.25 \times$ concentrated (i.e. 4 parts of electrolyte stock solution +1 part water to give the correct ionic composition in the simulated digestion fluids) and that $\mathrm{CaCl}_{2} \cdot\left(\mathrm{H}_{2} \mathrm{O}\right)_{2}$ was not added to the stock SSF, SGF and SIF solutions to avoid precipitation.

Samples were collected after each phase (oral, gastric and intestinal) of the in vitro digestion and the reaction of gastric phase (pepsin activity) was stopped by raising $\mathrm{pH}$ to 7.0 with $\mathrm{NaHCO}_{3}\left(1 \mathrm{~mol} \cdot \mathrm{L}^{-1}\right)$ and after full digestion, the reaction was stopped adding the enzyme inhibitor pefabloc $\left(1 \mathrm{mmol} \cdot \mathrm{L}^{-1}\right)(10 \mu \mathrm{L}$ per $1 \mathrm{~mL}$ of sample). All samples were tested at least in triplicate.

Porcine pepsin, pancreatin $(8 \times \mathrm{USP})$, bile extract porcine, $\mathrm{HCl}$, $\mathrm{NaHCO}_{3},\left(\mathrm{NH}_{4}\right)_{2} \cdot \mathrm{CO}_{3}$ and pefabloc SC (4-(2-aminoetyl) benenesulfonyl fluoride) were purchased from Sigma-Aldrich (St. Louis, MO). $\mathrm{NaOH}$, $\mathrm{KCl}, \mathrm{CaCl}_{2} \cdot\left(\mathrm{H}_{2} \mathrm{O}\right)_{2}, \mathrm{KH}_{2} \mathrm{PO}_{4}$ and $\mathrm{NaCl}$ were obtained from Panreac (Spain) and $\mathrm{MgCl}_{2} \cdot\left(\mathrm{H}_{2} \mathrm{O}\right)_{6}$ was purchased from Merck.

\subsection{Oligosaccharides quantification by HPLC}

Samples from the in vitro assays (Sections 2.5 and 2.6) were analyzed using an HPLC system (Shimadzu) equipped with a Prevail Carbohydrate ES $5 \mathrm{u}$ column $(5 \mu \mathrm{m}, 25 \times 0.46 \mathrm{~cm}$ length $\times$ diameter $)$ (Alltech). Sugars separation was performed using a mixture of acetonitrile (HPLC Grade, Carlo Erba, France) in pure-water (70:30 v/v), and $0.04 \%$ of ammonium hydroxide (HPLC Grade, Sigma-Aldrich, Germany). The elution was conducted at $1 \mathrm{~mL} \cdot \mathrm{min}^{-1}$ flow rate and the column temperature was maintained at $25^{\circ} \mathrm{C}$ (Nobre et al., 2018). Samples were sent to a Sedex 55 evaporative light scattering detector (ELSD) (Sedere, Alfortville, France) working with a drift tube temperature set at $50^{\circ} \mathrm{C}$ and nitrogen gas as nebulizing gas, at a pressure of 3.5 bar. The chromatographic signal was recorded and further integrated using the software LabSolutions (Shimadzu).

FOS standards (1-kestose, nystose, and $1^{\mathrm{F}}$-fructofuranosylnystose) were acquired from Wako (Japan). Sucrose and fructose standards were obtained from Merck and glucose from VWR (Belgium).

\subsection{Statistical analysis}

The digestion of FOS by simulating the environment of the mouth, stomach and small intestine was performed at least in triplicate and data was analyzed using the open source statistical program $\mathrm{R}$ (version 2.15 .1 ) at $5 \%$ of significance level. A one-way analysis of variance (ANOVA) was used to evaluate the effect of the digestive conditions in the percentage value of each FOS. If no significant interaction effect was found, for each statistical significant factor, means were compared using the Tukey's multiple comparison test. Shapiro-Wilk and 
Table 2

Oligosaccharides composition expressed as degree of polymerization of the fructo-oligosaccharides (FOS) samples tested. Data obtained by HPLC.

\begin{tabular}{|c|c|c|c|c|c|}
\hline \multirow[t]{2}{*}{ Carbohydrate } & \multicolumn{4}{|c|}{ Sugar $\left(\%\left(\mathrm{~g}_{\mathrm{FOS}} \cdot \mathrm{g}_{\text {total sugar }}{ }^{-1}\right)\right)$} & \multirow{2}{*}{$\begin{array}{l}\text { Total FOS }(\% \\
-\left(g_{\text {FOs }} \cdot g_{\text {total }}\right. \\
\left.\left.\text { sugar }^{-1}\right)\right)\end{array}$} \\
\hline & DP3 & DP4 & DP5 & DP6 & \\
\hline $\begin{array}{l}\text { FOS (Aspergillus } \\
\text { ibericus) }\end{array}$ & 39 & 50 & 4 & 0 & 93 \\
\hline $\begin{array}{l}\text { FOS (Aureobasidium } \\
\text { pullulans) }\end{array}$ & 33 & 53 & 7 & 0 & 93 \\
\hline Raftilose ${ }^{\circ} 95$ & $33^{\mathrm{a}}$ & $30^{\mathrm{a}}$ & $20^{\mathrm{a}}$ & $5^{\mathrm{a}}$ & $95^{\mathrm{b}}$ \\
\hline
\end{tabular}

DP: Degree polymerization.

a Determined in this work by HPLC.

b Data obtained from the producer (Based on manufacturer's analysis oligosaccharides with DP up to 7 are present. However, in the present work, we could not detect by HPLC the higher oligosaccharides).

Anderson-Darling normality tests were used to confirm a normal distribution of data. Results were considered significantly different for $p$ values $<0.05$

Results of the increase in cell density values for a given strain, for each carbohydrate tested, are given as mean \pm Standard Deviation.

All statistical tests were conducted at a 5\% significance level.

\section{Results and discussion}

FOS can be either produced by enzymatic trans-fuctosylation of sucrose by fructo-furanosidases (invertase) and fructosyl-transferase (inulosucrase and levansucrase) or by controlled hydrolysis of inulin by inulinases. The oligosaccharides resulting from these processes may have different chemical structures, not only due to their source, but also depending on the fungal or bacterial enzymes used. Consequently, the prebiotic properties and fermentation of such FOS by the microbiota may also differ. Several studies conducted with different oligosaccharides have proved not only their different ability to be fermented, but also that individual strains have specific substrate preferences (Kaplan
\& Hutkins, 2000; Rada et al., 2008; Su et al., 2007).

In the current work, three FOS samples from different sources were studied: a commercial sample Raftilose P95; and two samples produced enzymatically, one by A. pullulans (AP) and the other one by $A$. ibericus (IB).

\subsection{Carbohydrates structure identification and quantification}

The composition of the FOS samples was analyzed by HPLC. Results are shown in Table 2.

GC-qMS analyses of the alditol acetate derivatives were performed. The monosaccharides fructose and glucose, the disaccharide sucrose, the trisaccharide 1-kestose, and the tetrasaccharide nystose were used as standards. The possible assignment of the remaining oligosaccharides was assessed by combining the information of the fragmentation pattern and the glycosidic linkage analyses, as summarized in Table 3 and represented in Fig. S1 (Supplementary material). The amount of each di- and trisaccharide identified is shown in Table 4. The amount of monosaccharides is presented as equivalents of glucose, while di- and trisaccharides are depicted as equivalents of sucrose, i.e. they were calculated with the response factor of glucose and sucrose, respectively. The total content of trisaccharides determined by GC-qMS were $31 \%$, $28 \%$, and $30 \%$ for Raftilose ${ }^{\circ}$ P95, FOS from A. pullulans (AP), and FOS from $A$. ibericus (IB), respectively, that are in accordance with the results obtained by HPLC (Table 2).

The fragmentation patterns of the detected di- and trisaccharides derivatives allowed to differentiate the reducing from the non-reducing structures. The non-reducing structures are not modified when submitted to a borohydride reduction, giving origin to one single derivative. On the contrary, reducing oligosaccharides are transformed by borohydride into the respective alditols, resulting single derivatives 2 Da heavy. The ion at $m / z 375$, which corresponds to the mass of a pentaacetylated hexose residue, is diagnostic of the reducing oligosaccharides (Table 3 ). When the reducing oligosaccharide contains a fructose residue in the reducing end, the reaction with borohydride forms 2 epimeric alditols, and the consequent formation of two peaks in the chromatogram. Besides sucrose, other non-reducing disaccharides

Table 3

Retention time, fragmentation pattern and possible assignment of oligosaccharides present in Raftilose ${ }^{\circ}$ P95, FOS sample produced by Aureobasidium pullulans (AP), and Aspergillus ibericus (IB) samples.

\begin{tabular}{|c|c|c|c|c|}
\hline Peak $^{\mathrm{a}}$ & $t_{R}^{a}$ & Fragmentation pattern ${ }^{\mathrm{b}}$ & Possible assignment & Glycosidic linkages \\
\hline \multicolumn{5}{|c|}{ Present in all samples } \\
\hline A & 28.68 & $\begin{array}{l}153 \text { (1 } 00) ; 375 \text { (70.6); } 211 \text { (54.3); } 169 \text { (24.9); } 128 \text { (22.7); } 109 \\
(20.3) ; 433 \text { (18.4) }\end{array}$ & Inulobiose $[\mathrm{Fru}(\beta 2 \rightarrow 1) \mathrm{Fru}]$ & t-Fru; 1-Fru \\
\hline $\mathrm{C}$ & 29.41 & $\begin{array}{l}153 \text { (1 } 00) ; 375 \text { (69.2); } 211 \text { (49.3); } 169 \text { (21.8); } 128 \text { (27.0); } 433 \\
(20.6) ; 109 \text { (12.1) }\end{array}$ & Inulobiose $[\mathrm{Fru}(\beta 2 \rightarrow 1) \mathrm{Fru}]$ & t-Fru; 1-Fru \\
\hline \multicolumn{5}{|c|}{ Only present in microbial-derived FOS } \\
\hline B & 29.04 & $\begin{array}{l}153 \text { (1 } 00) ; 375 \text { (61.9); } 211 \text { (47.9); } 169 \text { (25.2); } 128 \text { (24.6); } 109 \\
(14.5) ; 433 \text { (19.3) }\end{array}$ & {$[\mathrm{Fru}(\alpha 2 \rightarrow 6) \mathrm{Glc}] /[\mathrm{Fru}(\beta 2 \rightarrow 6) \mathrm{Glc}]$} & t-Fru; 6-Glc \\
\hline 22 & 41.38 & $\begin{array}{l}211 \text { (1 } 00) ; 169 \text { (66.4); } 109 \text { (40.9); } 331 \text { (33.4); } 101 \text { (15.6); } 127 \\
(10.3) ; 128 \text { (6.6); }\end{array}$ & $\begin{array}{l}{[\mathrm{Fru}(\beta 2 \rightarrow 6) \mathrm{Glc}(\alpha 1 \leftrightarrow \beta 2) \mathrm{Fru}] /[\mathrm{Fru}(\beta 2 \rightarrow 6) \mathrm{Glc}(\alpha 1 \leftrightarrow} \\
\alpha 1) \mathrm{Glc}] /[\mathrm{Glc}(\alpha 1 \rightarrow 6) \mathrm{Glc}(\alpha 1 \leftrightarrow \beta 2) \mathrm{Fru}]\end{array}$ & $\begin{array}{l}\text { t-Fru; 6-Glc/t-Fru; 6-Glc; t-Glc/t-Glc; } \\
\text { 6-Glc; t-Fru }\end{array}$ \\
\hline $\mathrm{D}$ & 41.77 & $\begin{array}{l}375 \text { (1 } 00) ; 211 \text { (69.0); } 153 \text { (59.0); } 169 \text { (29.0); } 331 \text { (23.0); } 109 \\
\text { (14.7); } 128 \text { (14.6); }\end{array}$ & $\mathrm{R}$ & \\
\hline $\mathrm{E}$ & 41.92 & $\begin{array}{l}375 \text { (1 } 00 \text { ); } 153 \text { (64.0); } 211 \text { (58.3); } 273 \text { (27.0); } 169 \text { (20.3); } 331 \\
\text { (19.4); } 109 \text { (12.1); } 128 \text { (12.0); }\end{array}$ & $\mathrm{R}$ & \\
\hline $\mathrm{F}$ & 42.02 & $\begin{array}{l}375 \text { (1 } 00) ; 211 \text { (65.0); } 153 \text { (51.1); } 169 \text { (29.0); } 331 \text { (21.2); } 109 \\
(16.0) ; 128 \text { (13.1); }\end{array}$ & $\mathrm{R}$ & \\
\hline \multicolumn{5}{|c|}{ Only present in FOS (AP) } \\
\hline 23 & 41.45 & $\begin{array}{l}169 \text { (1 } 00) ; 211 \text { (62.8); } 109 \text { (47.7); } 331 \text { (38.45); } 127 \text { (13.4); } \\
271 \text { (8.3); } 128 \text { (6.8); }\end{array}$ & $\begin{array}{l}{[\mathrm{Fru}(\beta 2 \rightarrow 6) \mathrm{Glc}(\alpha 1 \leftrightarrow \beta 2) \mathrm{Fru}] /[\mathrm{Fru}(\beta 2 \rightarrow 6) \mathrm{Glc}(\alpha 1 \leftrightarrow} \\
\alpha 1) \mathrm{Glc}] /[\mathrm{Glc}(\alpha 1 \rightarrow 6) \mathrm{Glc}(\alpha 1 \leftrightarrow \beta 2) \mathrm{Fru}]\end{array}$ & $\begin{array}{l}\text { t-Fru; 6-Glc/t-Fru; 6-Glc; } t \text {-Glc/t-Glc; } \\
\text { 6-Glc; } t \text {-Fru }\end{array}$ \\
\hline \multicolumn{5}{|c|}{ Only present in Raftilose ${ }^{\circ}$ P95 } \\
\hline G & 41.18 & $\begin{array}{l}375 \text { (1 } 0 \text { 0); } 211 \text { (75.0); } 153 \text { (60.3); } 169 \text { (47.1); } 109 \text { (26.0); } 331 \\
\text { (25.0); } 128 \text { (15.8); }\end{array}$ & Inulotriose $[\mathrm{Fru}(\beta 2 \rightarrow 1) \mathrm{Fru}(\beta 2 \rightarrow 1) \mathrm{Fru}]$ & $t$-Fru; 1-Fru \\
\hline $\mathrm{H}$ & 41.41 & $\begin{array}{l}375 \text { (1 } 00) ; 211 \text { (72.2); } 153 \text { (53.7); } 169 \text { (41.0); } 331 \text { (23.3); } 109 \\
\text { (23.0); } 128 \text { (13.8); }\end{array}$ & Inulotriose $[\mathrm{Fru}(\beta 2 \rightarrow 1) \mathrm{Fru}(\beta 2 \rightarrow 1) \mathrm{Fru}]$ & $t$-Fru; 1-Fru \\
\hline
\end{tabular}

\footnotetext{
${ }^{\text {a }}$ Retention time (minutes) in the DB-1 column, according to Fig. S1.

b Values in parentheses are the relative intensities of the fragments.
} 
Table 4

Amount of carbohydrates identified in the FOS sample produced by Aspergillus ibericus (IB), Aureobasidium pulllulans (AP) and commercial Raftilose ${ }^{\circledR}$ P95.

\begin{tabular}{|c|c|c|c|c|c|c|c|}
\hline & \multirow[b]{2}{*}{ Assignment } & \multicolumn{2}{|l|}{ FOS (IB) } & \multicolumn{2}{|l|}{ FOS (AP) } & \multicolumn{2}{|c|}{ Raftilose ${ }^{\circ}$ P95 } \\
\hline & & $\bar{X}\left(m g \cdot g^{-1}\right)$ & RSD (\%) & $\bar{X}\left(\mathrm{mg} \cdot \mathrm{g}^{-1}\right)$ & RSD (\%) & $\bar{X}\left(m g \cdot g^{-1}\right)$ & RSD (\%) \\
\hline & Fructose $^{\mathrm{a}}$ & 5.0 & 7 & 13.0 & 5 & 38.4 & 2 \\
\hline & Glucose $^{\mathrm{a}}$ & 2.3 & 4 & 6.2 & 11 & 12.8 & 4 \\
\hline \multirow[t]{2}{*}{ [1-6] } & $\mathrm{NR}$ & traces & & traces & & - & \\
\hline & Sucrose $^{a}$ & 72.8 & 2 & 70.2 & 4 & 14.6 & 13 \\
\hline$A+C$ & Inulobiose & 27.1 & 3 & 25.7 & 9 & 36.1 & 6 \\
\hline B & Blastose & 7.2 & 1 & 12.3 & 12 & - & \\
\hline \multirow[t]{2}{*}{ [7-21] } & NR & traces & & traces & & - & \\
\hline & 1-kestose $\mathrm{e}^{\mathrm{a}}$ & 259.1 & 3 & 242.1 & 5 & 31.7 & 13 \\
\hline 22 & NR & 18.8 & 33 & 9.9 & 35 & - & \\
\hline 23 & NR & - & & 8.0 & 26 & - & \\
\hline $\mathrm{D}$ & $\mathrm{R}$ & 7.4 & 29 & 5.2 & 33 & - & \\
\hline E & $\mathrm{R}$ & 1.6 & 15 & 3.0 & 11 & - & \\
\hline $\mathrm{F}$ & $\mathrm{R}$ & 8.3 & 11 & 7.1 & 19 & - & \\
\hline $\mathrm{G}+\mathrm{H}$ & Inulotriose & 280.7 & 17 & - & & - & \\
\hline
\end{tabular}

${ }^{\text {a }}$ Retention time and mass spectra confirmed by comparison with standards. $\overline{\mathrm{X}}$ - average amount of the carbohydrate; RSD - Relative Standard Deviation; NR Non-reducing sugar; R - Reducing sugar.

were detected by GC-qMS (Table 4, peaks [1-6]). These disaccharides are likely products of culture medium or fungi metabolism, composed by galactose and mannose, detected in small amounts by methylation analysis (Table 5). The presence of small amounts of terminally-linked mannose (t-Man) and 1,2,6-Man residues could be indicative of the presence of small fragments of mannoproteins from yeast or fungi cell walls (Bastos, Coelho, \& Coimbra, 2015). Beyond the oligosaccharides identified based on the standards used, other di- and trisaccharides were detected based on the retention time and MS fragmentation pattern. Their tentative assignment was proposed in Table 3 combining the MS data with the glycosidic linkages type and relative abundance observed for each sample (Table 5).

Concerning reducing disaccharides, peaks $\mathrm{A}$ and $\mathrm{C}$, present in all samples, were more abundant in Raftilose ${ }^{\circledast}$ P95 $\left(36.1 \mathrm{mg} \cdot \mathrm{g}^{-1}\right)$. The glycosidic linkage analysis of Raftilose P95 showed only $(2 \rightarrow 1)$ Fru $(40.5 \%)$ as reducing sugar with fructose at the reducing end. As this results from the inulin hydrolysis, it should be linked to $t$-Fru (33.6\%), thus corresponding to inulobiose $[\mathrm{Fru}(2 \rightarrow 1) \mathrm{Fru}]$. The high abundance

Table 5

Glycosidic linkage composition of the FOS samples produced by Aspergillus ibericus (IB), Aureobasidium pullulans (AP) and commercial Raftilose $\mathrm{P} 95$.

\begin{tabular}{|c|c|c|c|c|c|c|c|}
\hline \multicolumn{2}{|c|}{ Glycosidic linkage } & \multicolumn{2}{|c|}{ FOS (IB) } & \multicolumn{2}{|c|}{ FOS (AP) } & \multicolumn{2}{|c|}{ Raftilose $^{\circledR}$ P95 } \\
\hline & & $\begin{array}{l}\bar{X} \\
(\mathrm{~mol} \\
\%)\end{array}$ & RSD (\%) & $\begin{array}{l}\bar{X} \\
(\mathrm{~mol} \\
\%)\end{array}$ & RSD (\%) & $\begin{array}{l}\bar{X} \\
\text { (mol } \\
\%)\end{array}$ & RSD (\%) \\
\hline t-Fru & & 23.1 & 4 & 33.0 & 10 & 33.6 & 17 \\
\hline 1-Fru & & 34.6 & 2 & 22.0 & 9 & 40.5 & 13 \\
\hline 1,6-Fru & & 0.6 & 12 & 0.6 & 13 & 1.3 & 3 \\
\hline \multirow[t]{2}{*}{ 1,3-Fru } & & - & - & - & - & 1.1 & 7 \\
\hline & Total & 58.3 & 1 & 55.6 & 2 & 76.5 & 0.4 \\
\hline t-Glc & & 36.1 & 2 & 37.9 & 0.1 & 22.1 & 3 \\
\hline 4-Glc & & 0.8 & 9 & 0.6 & 10 & 0.9 & 11 \\
\hline 6-Glc & & 4.5 & 5 & 5.4 & 19 & 0.5 & 29 \\
\hline 2,3-Glc & & 0.1 & 24 & 0.1 & 20 & - & - \\
\hline \multirow[t]{2}{*}{ 3,4-Glc } & & traces & - & 0.1 & 0 & - & - \\
\hline & Total & 41.6 & 1 & 44.1 & 2 & 23.5 & 1 \\
\hline \multirow[t]{2}{*}{$\mathrm{t}-\mathrm{Gal}$} & & 0.1 & 4 & 0.1 & 5 & - & - \\
\hline & Total & 0.1 & 4 & 0.1 & 5 & - & \\
\hline t-Man & & - & - & traces & - & - & - \\
\hline \multirow[t]{2}{*}{ 2,6-Man } & & traces & - & 0.4 & 38 & - & - \\
\hline & Total & traces & - & 0.4 & 38 & - & - \\
\hline
\end{tabular}

$\overline{\mathrm{X}}$ - average; RSD - Relative Standard Deviation. of $t$-Glc (22.1\%) most probably result from sucrose, also composed by $t$ Fru, and 1-kestose and nystose oligosaccharides, also composed by $t$-Fru and $(2 \rightarrow 1)$ Fru. Peak B, absent in Raftilose P95 sample, could be composed by $t$-Fru, $t$-Glc, $(1 \rightarrow 6)$ Glc, given that these were the most abundant glycosidic linkages of the FOS from A. pullulans (AP) and from A. ibericus (IB) without fructose at the reducing end. Therefore, the possible peak B structures are [Fru( $2 \rightarrow 6) \mathrm{Glc}]$ and [Glc $(1 \rightarrow 6) \mathrm{Glc}]$. As the MS spectra and retention time do not correspond to isomaltose [Glc $(\alpha 1 \rightarrow 6)$ Glc] or gentiobiose [Glc $(\beta 1 \rightarrow 6) \mathrm{Glc}$ ], the peak B was assigned to $[\mathrm{Fru}(2 \rightarrow 6) \mathrm{Glc}]$. As blastose $[\mathrm{Fru}(\beta 2 \rightarrow 6) \mathrm{Glc}]$ is reported to be a secondary product of fructosyltransferase reactions when using sucrose as substrate (Flieger et al., 2005; Santos-Moriano et al., 2015), peak B was assigned as blastose.

A total of 15 different non-reducing trisaccharides were identified by GC-qMS in the FOS samples produced by microorganisms. These peaks were assigned as 7-21 and they are present in very small amounts. Another two non-reducing trisaccharides were found (assigned as peak 22 and 23). Considering the glycosidic linkages found for FOS (AP) and FOS (IB) samples, and the non-reducing character of peaks 22 and 23, there are three possible structures for these peaks (Table 3).

One of the possible assignments is neokestose $[\mathrm{Fru}(\beta 2 \rightarrow 6) \mathrm{Glc}(\alpha 1 \leftrightarrow$ $\beta 2) \mathrm{Fru}$, which is already reported as a product of sucrose transformation by fungi species (Yasuda, Shitoh, Yamano, Itoh, \& Shimura, 1986). In addition, $[\mathrm{Fru}(\beta 2 \rightarrow 6) \mathrm{Glc}(\alpha 1 \leftrightarrow \alpha 1) \mathrm{Glc}]$ and theanderose [Glc $(\alpha 1 \rightarrow 6) \mathrm{Glc}(\alpha 1 \leftrightarrow \beta 2) \mathrm{Fru}]$ are also possible structures. The non-reducing trisaccharide present in higher amounts for all the three samples was composed by residues of terminally-linked fructose ( $t$-Fru), terminallylinked glucose (t-Glc), and $(2 \rightarrow 1)$ Fru, suggesting the presence of a FOSinulin type, such as 1-kestose $\left(\mathrm{GF}_{2}\right)$. By comparison with results obtained by HPLC and Nuclear Magnetic Resonance (NMR), in a work conducted previously with samples from A. ibericus (Nobre et al., 2018), this peak was confirmed as 1-kestose. Three different reducing trisaccharides (assigned as D, E and F) were found in the samples from microorganisms, but not in Raftilose P95. Each peak was present in an amount up to $8 \mathrm{mg} \cdot \mathrm{g}^{-1}$ of sample, representing a maximum $1 \%$ content of the total oligosaccharides (w/w). Besides, another two peaks corresponding to reducing trisaccharides (assigned as $\mathrm{G}$ and $\mathrm{H}$ ) were found only in Raftilose ${ }^{\oplus 95}$. These sugars were detected in a considerable amount (up to $28 \%$ ). Possibly, peaks $\mathrm{G}$ and $\mathrm{H}$ are the sugar inulotriose, since the fragmentation pattern found is similar to that of inulobiose peaks and a high proportion of $(2 \rightarrow 1$-Fru linkage was found for this sample (Table 5). Raftilose ${ }^{\bullet}$ P95 is obtained from the hydrolysis of inulin, hence the presence of these two sugars was expected. 

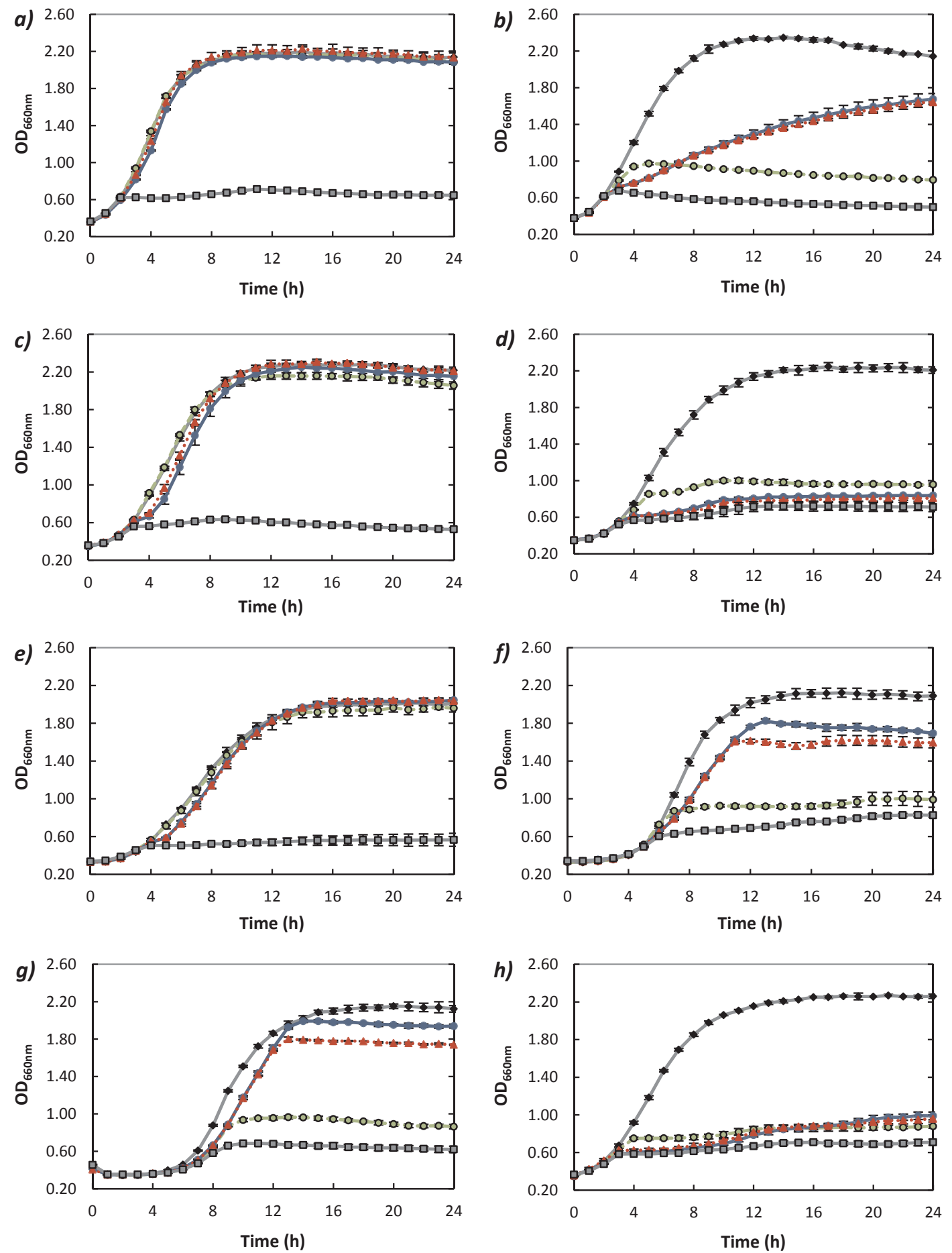

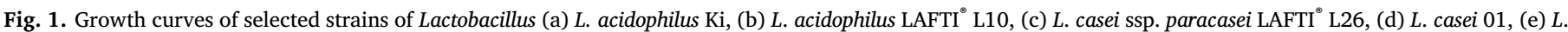

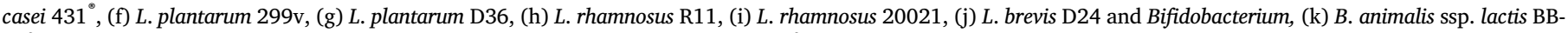

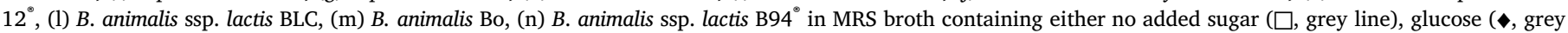

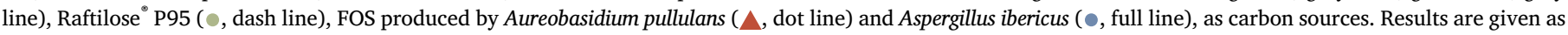
mean \pm SD.

Further, the $(2 \rightarrow 1,6)$ Fru residue may be indicative of the presence of FOS (tetra-, penta-, (...)saccharides) with the mixed type structure (Dfructofuranosyl- $(\beta 2 \rightarrow 1)_{m}$-[D-fructofuranosyl- $\left.(\beta 2 \rightarrow 6)\right]_{n}$-sucrose)

(Benkeblia, 2013), since the remaining residues of these oligosaccharides were also found (t-Fru, t-Glc and $(2 \rightarrow 1)$ Fru). However, the polymerization occurs via the $m$ pathway, since the $(2 \rightarrow 6)$ Fru residue was not found in any sample. Oligosaccharides containing an inulin type such as $1^{\mathrm{F}}$-fructofuranosylnystose were identified in the samples (Nobre et al. 2018). Inulin neoseries types, such as $1^{\mathrm{F}}, 6^{\mathrm{G}}$-Di- $\beta$-D-fructofuranosylsucrose, is also likely to be present due to the presence of $(1 \rightarrow$ 6)Glc, along with $(2 \rightarrow 1)$ Fru and t-Fru. 

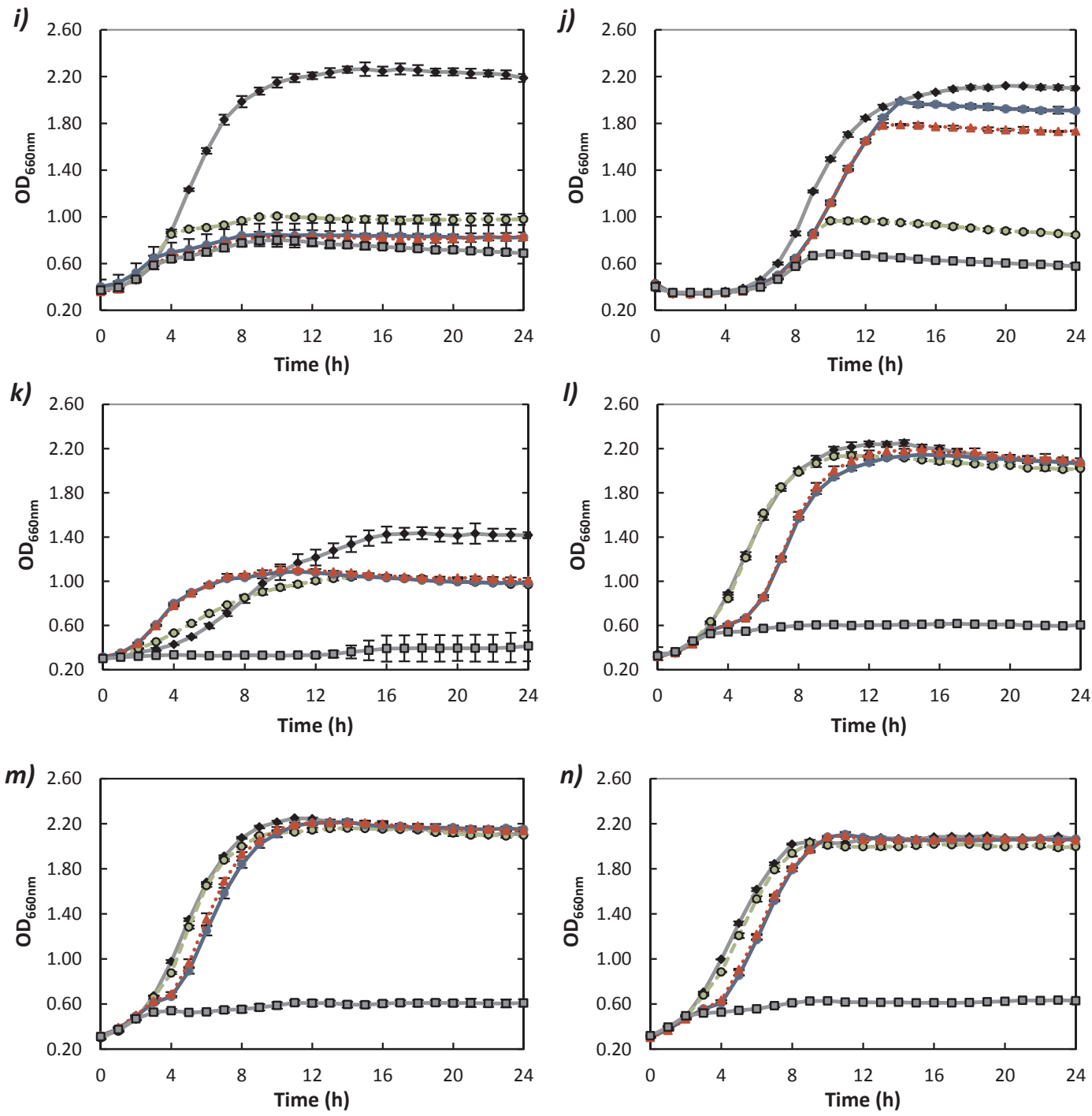

Fig. 1. (continued)

Table 6

Maximum $\mathrm{OD}_{660 \mathrm{~nm}}$ values obtained after $24 \mathrm{~h}$ of growth of Lactobacillus and Bifidobacterium strains in various carbon sources.

\begin{tabular}{|c|c|c|c|c|c|c|c|}
\hline Genus & Species & Strain & No sugar & Glucose & FOS (A. ibericus) & FOS (A. pullulans) & Raftilose ${ }^{\circ}$ P95 \\
\hline \multirow[t]{10}{*}{ Lactobacillus } & \multirow[t]{2}{*}{ acidophilus } & $\mathrm{Ki}$ & -- & +++ & +++ & +++ & +++ \\
\hline & & LAFTI $^{\circ}$ L10 & -- & +++ & + & + & - \\
\hline & \multirow[t]{3}{*}{ casei } & ssp. paracasei LAFTI ${ }^{\pi}$ L26 & -- & +++ & +++ & +++ & +++ \\
\hline & & 01 & -- & +++ & -- & -- & - \\
\hline & & 431 & -- & +++ & +++ & +++ & +++ \\
\hline & \multirow[t]{2}{*}{ plantarum } & $299 v$ & -- & +++ & ++ & + & - \\
\hline & & D36 & -- & +++ & ++ & + & - \\
\hline & \multirow[t]{2}{*}{ rhamnosus } & R11 & -- & +++ & - & - & - \\
\hline & & 20021 & -- & +++ & -- & -- & - \\
\hline & brevis & D24 & -- & +++ & ++ & + & - \\
\hline \multirow[t]{4}{*}{ Bifidobacterium } & \multirow[t]{4}{*}{ animalis } & $\begin{array}{l}\text { ssp. lactis } \\
\text { BB- } 12^{\circ}\end{array}$ & -- & $+/-$ & - & - & - \\
\hline & & ssp. lactis BLC & -- & +++ & +++ & +++ & +++ \\
\hline & & Bo & -- & +++ & +++ & +++ & +++ \\
\hline & & ssp. lactis B94 & -- & +++ & +++ & +++ & +++ \\
\hline
\end{tabular}

Values of $\mathrm{OD}_{660 \mathrm{~nm}}: \mathrm{OD}>2.0(+++) ; 2.0>\mathrm{OD}>1.8(++) ; 1.8>\mathrm{OD}>1.6(+) ; 1.6>\mathrm{OD}>1.4(+/-) ; 1.4>\mathrm{OD}>0.8(-)$; $\mathrm{OD}<0.8(--)$.

\subsection{In vitro carbon source utilization by probiotic bacteria}

Results of the Lactobacillus and Bifidobacterium strains growth, incubated either with no added sugar as carbon source (negative control) or supplemented with the four different carbon sources, are shown in Fig. 1.
For a given sugar compound to be considered a prebiotic it should be metabolized nearly as well as glucose is metabolized (Huebner et al., 2007). In this study, all microorganisms were found to grow well in the medium containing glucose as carbohydrate source (positive control). As expected, none of the microorganisms were able to grow without 
Table 7

In vitro digestion of oligosaccharides from different sources. The values are expressed as rate of hydrolysis at different phases of the digestion.

\begin{tabular}{|c|c|c|c|c|c|c|c|c|c|}
\hline \multirow{2}{*}{$\begin{array}{l}\text { Digestion } \\
\text { phase (\%) }\end{array}$} & \multicolumn{3}{|c|}{ FOS (A. ibericus) } & \multicolumn{3}{|c|}{ FOS (A. pullulans) } & \multicolumn{3}{|c|}{ Raftilose P95 } \\
\hline & $\mathrm{GF}_{2}$ & $\mathrm{GF}_{3}$ & $\mathrm{GF}_{4}$ & $\mathrm{GF}_{2}$ & $\mathrm{GF}_{3}$ & $\mathrm{GF}_{4}$ & $\mathrm{GF}_{2}$ & $\mathrm{GF}_{3}$ & $\mathrm{GF}_{4}$ \\
\hline Mouth & $1.0^{\mathrm{a}}$ & $0.0^{\mathrm{a}}$ & $0.0^{\mathrm{a}}$ & 0.3 & $0.0^{\mathrm{a}}$ & $0.0^{\mathrm{a}}$ & $0.0^{\mathrm{a}}$ & $0.2^{\mathrm{a}}$ & $0.0^{\mathrm{a}}$ \\
\hline Stomach & 1.5 & $0.9^{\mathrm{a}}$ & $0.0^{\mathrm{a}}$ & 2.0 & 1.1 & $0.0^{\mathrm{a}}$ & $1.0^{\mathrm{a}}$ & $1.4^{\mathrm{a}}$ & $0.0^{\mathrm{a}}$ \\
\hline Small Intestine & $1.2^{\mathrm{a}}$ & 5.5 & $0.0^{\mathrm{a}}$ & 0.1 & 4.3 & $0.0^{\mathrm{a}}$ & $0.9^{\mathrm{a}}$ & $0.0^{\mathrm{a}}$ & 1.4 \\
\hline
\end{tabular}

a The values of the sugar concentration obtained between each digestion phase are not significantly different $(p>0.05)$.

sugar supplementation, as observed by the negative control (Fig. 1).

Five of the fourteen strains tested exhibited an increased cell density after $24 \mathrm{~h}$ growing in glucose as compared to their growth in media containing oligosaccharides such as L. acidophilus ssp. LAFTI $^{\oplus}$ L10, L. casei 01 and L. rhamnosus $\mathrm{R} 11$, L. rhamnous 20,021 and B. animalis ssp. lactis BB-12 (Fig. 1 and Table 6). Likewise, Huebner et al., 2007 reported a study with ten different microorganisms metabolizing five types of prebiotics, among which, from fifty possible combinations, thirty-seven exhibited a cell density significantly lower when grown on the prebiotic as compared to glucose. Concerning the $B$. animalis ssp. lactis BB- $12{ }^{\oplus}$ strain, although it had achieved a high cell density when grown in glucose, it grew much slower than in the other substrates, as shown by the specific growth rates determined $\left(0.133 \pm 0.003 \mathrm{~h}^{-1}\right.$ in glucose and $>0.2 \mathrm{~h}^{-1}$ in FOS) (Table S1). In the current study, although L. plantarum 299v, L. plantarum D36 and L. brevis D24 also grew better/faster in glucose than in oligosaccharides, according to their specific growth rates ( $>0.35 \mathrm{~h}^{-1}$ in glucose) (Table S1), the differences between the maximum OD $_{660 \mathrm{~nm}}$ obtained after $24 \mathrm{~h}$ for glucose and FOS produced by $A$. ibericus were less significant (Fig. 1 and Table 6). On the other hand, a similar growth trend was found for L. acidophilus Ki, L. casei ssp. paracasei LAFTI ${ }^{\oplus}$ L26, L. casei 431, B. animalis ssp. lactis BLC, $B$. animalis Bo and $B$. animalis ssp. lactis B94 $4^{\circ}$ using glucose as compared to oligosaccharides (Table S1). Bifidobacterium animalis ssp. lactis BLC achieved the same maximum optical density (OD $\left.{ }_{660 \mathrm{~nm}}: 2.2\right)$ at $24 \mathrm{~h}$ for all carbon sources although, while growing in glucose and commercial FOS, its lag phase was $2 \mathrm{~h}$ shorter than the one obtained for fermentations with FOS from A. pulullans and A. ibericus (Fig. 1).

The rate at which probiotic microorganisms can grow on a specific carbon source will influence their ability to compete with other intestinal bacteria in the colon. Thus, the prebiotic activity degree of a specific carbohydrate is related with the extent to which the carbohydrate is converted into biomass (Huebner et al., 2007).

The results gathered in the current study suggest that the fermentation of the potential prebiotic compounds assessed depends on the bacterial strain used rather than on the species or genera. For example, L. casei ssp. paracasei LAFTI $^{\circledR}$ L26 and $L$. casei 431 exhibited ODs $_{660 \mathrm{~nm}}$ higher than 2.0 with all carbon sources, while the cell density of $L$. casei 01 almost did not increase when using FOS as carbon source. The same behavior was observed for L. acidophilus and B. animalis. Accordingly, in a study conducted with bacterial isolates from infants, the values of specific growth in Raftilose ${ }^{\circledast 95}$ for B. longum, B. animalis, B. bifidum and $B$. breve were considerably different depending on the strain (Rada et al., 2008). Huebner et al. (2007) also found a different prebiotic score when growing different strains from the same species of L. plantarum and L. acidophilus in Raftilose ${ }^{\oplus}$ P95. More recently, Chung et al. (2016) found that inulin and pectin exert highly selective effects upon the gut microbiota at the level of individual species but not at the phylum level. Very small overlap on the growth was found for the two substrates in the species promoted thereby.

Bifidobacterium strains achieved similar cell densities, independently of the carbon source used (Table 6). On the other hand, for some Lactobacillus strains, the cell densities obtained may depend on the FOS type being metabolized. In the present work, the studied strains tended to grow more with the FOS synthesized by $A$. ibericus, followed by the ones from $A$. pullulans, and then the commercial FOS (Table 6). This was more evident for L. plantarum 299v, L. plantarum D36 and L. brevis D24 strains. These results may be explained by the different di- and trisaccharides profiles, specially of FOS (AP) and FOS (IB) when compared with the commercial Raftilose P95. A great variability of oligosaccharide chemical structures can be attained depending on the fermentation conditions, substrates and the source of enzymes used during their synthesis (Cardelle-Cobas et al., 2011). FOS (AP) and FOS (IB) samples have the compounds corresponding to peaks B (possibly blastose) and 22, and also a higher amount of 1-kestose than the commercial FOS sample. Blastose is the basis of the neofructooligosaccharide (neoFOS) series and this type of FOS has been reported to have superior bifido-stimulating effect, as well as better chemical and thermal stability than other oligosaccharides (MirandaMolina, Castillo, \& Lopez Munguia, 2017). On the other hand, Raftilose P95 presents the compounds $\mathrm{G}+\mathrm{H}$ (possibly inulotriose), and a higher amount of $\mathrm{A}+\mathrm{C}$ (possibly inulobiose). Concerning the enzymatically produced samples, the main difference is the higher amount of compound corresponding to peak 22 (possibly neokestose) in FOS (IB). Neokestose has been shown to improve the population of bifidobacteria and lactobacilli to a greater extent than commercial FOS, and to inhibit Clostridia and the development of cancer cells (Miranda-Molina, et al., 2017). Therefore, the amount of this compound could justify the higher prebiotic activity of FOS produced by A. ibericus in Lactobacillus strains. Indeed, the individual strains' lag phase, cell densities and growth rates are affected by the structure and/or degree of polymerization of the different FOS source (Li et al. 2015). These factors can possibly justify the differences obtained for fermentations conducted with the different FOS and consequently, this will be further reflected in their potential prebiotic properties.

In summary, from the in vitro tests conducted with probiotic bacteria it was possible to confirm the prebiotic-like potential of the FOS produced by the new isolated $A$. ibericus strain, as well as the FOS produced by the A. pullulans.

\subsection{In vitro digestion of oligosaccharides}

Additionally, to consider a given oligosaccharide as a potential prebiotic, it is necessary to guarantee that a significant amount of the carbohydrate reaches the large intestine (Roberfroid, 2007). The digestion of the three different FOS (Table 2) was investigated following a standardized in vitro method described elsewhere (Minekus et al., 2014). The hydrolysis degrees obtained by simulating the environment of the mouth, stomach and small intestine are shown in Table 7. The percentage of each carbohydrate moiety in each phase consists in the difference of oligosaccharides amounts between the beginning and the end of the respective digestion phase. Only results with statistically significant differences $(p<0.05)$ have been considered.

None of the oligosaccharides was hydrolyzed during the first phase of the digestion, i.e. the simulation of the oral phase with salivary fluid.

1-Kestose $\left(\mathrm{GF}_{2}\right)$, synthesized by $A$. pullulans and $A$. ibericus, was slightly hydrolyzed in the second phase of the digestion either by the gastric fluid or due to the exposure to a low $\mathrm{pH}$. Nevertheless, the degree of hydrolysis was still lower than $2.0 \%$. In the third phase, corresponding to the simulation of the conditions of the small intestine, no hydrolysis was found for 1-kestose. Likewise, in a study conducted with commercial 1-kestose (supplied by Wako Pure Chemical Industries, Ltd. (Tokyo)), Suzuki, Tanaka, Amano, Asakura, and Muramatsu (2004) found a small degree of hydrolysis with artificial pancreatic juice (7\%), but in the presence of artificial saliva and small intestine enzymes 1kestose remained undigested.

Nystose $\left(\mathrm{GF}_{3}\right)$, also synthesized by $A$. ibericus and $A$. pullulans, was slightly hydrolyzed during the simulation of the small intestine digestion due to enzymatic hydrolysis. A reduction of $5.5 \%$ of the amounts of nystose from $A$. ibericus and $4.3 \%$ from $A$. pullulans was found at the end 
of the digestion.

Fructo-furanosylnystose $\left(\mathrm{GF}_{4}\right)$, probably due to its higher degree of polymerization, was more resistant to hydrolysis than the other two oligosaccharides. As a result, no significant hydrolysis was found in the tests carried out with this oligosaccharide during all simulated digestion phases.

Digestibility of single oligosaccharides has been shown to vary markedly depending on the oligosaccharide type and is more pronounced for the short-chain ones (Marx, Winkler, \& Hartmeier, 2000). The hydrolysis of long-chain FOS may be prevented by steric hindrance at the active site of the hydrolytic enzymes (Marx et al., 2000). Therefore, for the two different FOS samples studied (synthesized by $A$. pullulans and A. ibericus), the decisive factor for degradation was based on the molecular mass of the oligosaccharide.

In a study conducted with neosugars, produced from sucrose by $A$. niger enzymes, a difficult digestion was also found for human salivary enzymes, rat pancreatic and small intestinal mucosa homogenates (Hidaka, Eida, Takizawa, Tokunaga, and Tashiro, 1986). The authors concluded that the neosugars are not hydrolyzed by animal digestive enzymes such as alpha-amylase and small intestinal digestive enzymes.

In vitro digestion experiments demonstrated that the commercial FOS, Raftilose P95, was highly resistant to the enzymes of the upper gastrointestinal tract. In the present study, after each digestion phase, $>98.5 \%$ of each oligosaccharide was recovered. Raftilose P95 is produced by partial enzymatic hydrolysis of inulin yielding inulintype saccharides, mostly composed by $75 \%$ of fructose-only chains $\left(\mathrm{FF}_{\mathrm{n}}\right)$ with degrees of polymerization ranging from 2 to 7 , while oligosaccharides produced from sucrose by fungi enzymes, always exhibit a glucose as a terminal residue in their composition $\left(\mathrm{GF}_{\mathrm{n}}\right)$, with degrees of polymerization ranging from 2 to 4 (Nobre, Cerqueira, Rodrigues, Vicente, \& Teixeira, 2015; Shoaf, Mulvey, Armstrong, \& Hutkins, 2006). Accordingly, we did find a high proportion of $(2 \rightarrow 1)$ Fru linkage in the Raftilose P95 sample, that suggests the presence of a great content of sugars like inulobiose and inulotriose.

The differences on the molecule configuration and type of glycosidic linkages might explain the difference in resistance to the enzymes and low $\mathrm{pH}$ values.

\section{Conclusions}

In vitro tests conducted with commercial probiotic bacteria showed that FOS produced both by the new isolated $A$. ibericus strain and $A$. pullulans exhibit a promising prebiotic potential. The FOS sample obtained was able to stimulate the growth of probiotic strains $\left(\mathrm{ODs}_{660 \mathrm{~nm}}\right.$ higher than 1.8 were obtained for most strains) and was simultaneously resistant to hydrolysis along the simulated harsh conditions of the gastrointestinal system ( $>98.5 \%$ of each oligosaccharide was recovered after digestion), thus suggesting that it could reach the large intestine intact.

Oligosaccharides that were present only in samples of FOS produced by the microorganisms were detected and identified. It was possible to assign blastose and neokestose based on fragmentation pattern and glycosidic linkage. On the other hand, high proportion of $(2 \rightarrow 1)$ Fru linkages was found for the Raftilose P95 sample, suggesting the presence of a great content of oligosaccharides like inulobiose and inulotriose.

Additionally, the fermentation of the FOS samples was found to be both substrate and strain specific, rather than based on the species or genera. Concerning the cell densities obtained, the lactobacilli probiotic strains tested preferentially metabolized the microbial-derived FOS obtained than Raftilose P95, whereas bifidobacteria demonstrated equivalent metabolizing capacity of all FOS samples.

The results gathered in the current work provide a basis for further optimization of the combined use of probiotics and potential prebiotics envisaging their application as symbiotics in the design of new addedvalue functional foods.

\section{Conflict of interest}

The authors declare no conflicts of interest in this work.

\section{Ethics statments}

(1) This material has not been published in whole or in part elsewhere;

(2) The manuscript is not currently being considered for publication in another journal;

(3) All authors have been personally and actively involved in substantive work leading to the manuscript, and will hold themselves jointly and individually responsible for its content.

\section{Acknowledgements}

Clarisse Nobre, Sérgio Sousa, Elisabete Coelho and Ana Pinheiro acknowledge the Portuguese Foundation for Science and Technology (FCT) for their Post-Doc and Doc Grants (SFRH/BPD/87498/2012, SFRH/BD/105304/2014, SFRH/BPD/70589/2010, and SFRH/BPD/ $101181 / 2014$, respectively). This study was supported by the FCT under the scope of the strategic funding of UID/BIO/04469/2013 unit and COMPETE 2020 (POCI-01-0145-FEDER-006684) and BioTecNorte operation (NORTE-01-0145-FEDER-000004) funded by the European Regional Development Fund under the scope of Norte2020 - Programa Operacional Regional do Norte, also QOPNA research Unit (FCT UID/ QUI/00062/2013) through national funds and where applicable co-financed by the FEDER, within the PT2020 Partnership Agreement, project Essence (POCI-01-0247-FEDER-010887) for financial support of Post-Doc grant of Elisabete Coelho and, multi-purpose strategies for broadband agro-forest and fisheries by-products valorisation: a step forward for a truly integrated biorefinery SAICTPAC/0040/2015 (POCI-01-0145-FEDER-016403), Biomass and Bioenergy Research Infrastructure (01/SAICT/2016), also CBQF research centre by National Funds from FCT through project UID/Multi/50016/2013.

\section{Appendix A. Supplementary material}

Supplementary data associated with this article can be found, in the online version, at https://doi.org/10.1016/j.jff.2018.05.004.

\section{References}

Al-Sheraji, S. H., Ismail, A., Manap, M. Y., Mustafa, S., Yusof, R. M., \& Hassan, F. A. (2013). Prebiotics as functional foods: A review. Journal of Functional Foods, 5, 1542-1553.

Bastos, R., Coelho, E., \& Coimbra, M. A. (2015). Modifications of Saccharomyces pastorianus cell wall polysaccharides with brewing process. Carbohydrate Polymers, 124, 322-330.

Benkeblia, N. (2013). Fructooligosaccharides and fructans analysis in plants and food crops. Journal of Chromatography A, 1313, 54-61.

Bryk, G., Coronel, M. Z., Pellegrini, G., Mandalunis, P., Rio, M. E., de Portela, M. L. P. M., \& Zeni, S. N. (2015). Effect of a combination GOS/FOS ${ }^{\circledR}$ prebiotic mixture and interaction with calcium intake on mineral absorption and bone parameters in growing rats. European Journal of Nutrition, 54(6), 913-923.

Cardelle-Cobas, A., Corzo, N., Olano, A., Peláez, C., Requena, T., \& Ávila, M. (2011). Galactooligosaccharides derived from lactose and lactulose: Influence of structure on Lactobacillus, Streptococcus and Bifidobacterium growth. International Journal of Food Microbiology, 149, 81-87.

Castro, C. C., Nobre, C., Duprez, M.-E., De Weireld, G., \& Hantson, A.-L. (2017). Screening and selection of potential carriers to immobilize Aureobasidium pullulans cells for fructo-oligosaccharides production. Biochemical Engineering, 118, 82-90.

Chen, Q., Ren, Y., Lu, J., Bartlett, M., Chen, L., Zhang, Y., ... Liu, C. (2017). A novel prebiotic blend product prevents irritable bowel syndrome in mice by improving gut microbiota and modulating immune response. Nutrients, 9(12), 1341.

Chung, W. S. F., Walker, A. W., Louis, P., Parkhill, J., Vermeiren, J., Bosscher, D., ... Flint, H. J. (2016). Modulation of the human gut microbiota by dietary fibres occurs at the species level. BMC Biology, 14, 3.

Coelho, E., Rocha, M. A. M., Moreira, A. S. P., Domingues, M. R. M., \& Coimbra, M. A. (2016). Revisiting the structural features of arabinoxylans from brewers' spent grain. Carbohydrate Polymers, 139, 167-176.

Dominguez, A., Nobre, C., Rodrigues, L. R., Peres, A. M., Torres, D., Rocha, I., ... Teixeira, J. (2012). New improved method for fructooligosaccharides production by Aureobasidium pullulans. Carbohydrate Polymers, 89, 1174-1179. 
Flieger, M., Kantorová, M., Halada, P., Kuzma, M., Pažoutová, S., Stodůlková, E., \& Kolínská, R. (2005). Oligosaccharides produced by submerged cultures of Claviceps africana and Claviceps sorghi. Folia Microbiologica, 50(3), 198-204.

Franck, A. (2002). Technological functionality of inulin and oligofructose. British Journal of Nutrition, 87, S287-S291.

Frei, R., Akdis, M., \& O'Mahony, L. (2015). Prebiotics, probiotics, synbiotics, and the immune system. Current Opinion in Gastroenterology, 31(2), 153-158.

Gibson, G. R., Scott, K. P., Rastall, R. A., Tuohy, K. M., Hotchkiss, A., Dubert-Ferrandon, A., ... Buddington, R. (2010). Dietary prebiotics: Current status and new definition. Food Science and Technology Bulletin: Functional Foods, 7(1), 1-19.

Hidaka, H., Eida, T., Takizawa, T., Tokunaga, T., \& Tashiro, Y. (1986). Effects of fructooligosaccharides on intestinal flora and human health. Bifidobacteria Microflora, 5, 37-50.

Huebner, J., Wehling, R. L., \& Hutkins, R. W. (2007). Functional activity of commercial prebiotics. International Dairy Journal, 17, 770-775.

Kaplan, H., \& Hutkins, R. W. (2000). Fermentation of fructooligosaccharides by lactic acid bacteria and bifidobacteria. Applied and Environmental Microbiology, 66, 2682-2684.

Li, W., Wang, K., Sun, Y., Ye, H., Hu, B., \& Zeng, X. (2015). Influences of structures of galactooligosaccharides and fructooligosaccharides on the fermentation in vitro by human intestinal microbiota. Journal of Functional Foods, 13, 158-168.

Maiorano, A. E., Piccoli, R. M., Da Silva, E. S., \& De Andrade Rodrigues, M. F. (2008). Microbial production of fructosyltransferases for synthesis of prebiotics. Biotechnology Letters, 30, 1867-1877.

Mallappa, R. H., Rokana, N., Duary, R. K., Panwar, H., Batish, V. K., \& Grover, S. (2012). Management of metabolic syndrome through probiotic and prebiotic interventions. Indian Journal of Endocrinology and Metabolism, 16(1), 20-27.

Marx, S. P., Winkler, S., \& Hartmeier, W. (2000). Metabolization of beta-(2,6)-linked fructose-oligosaccharides by different bifidobacteria. FEMS Microbiology Letters, 182, 163-169.

Mattila-Sandholm, T., Myllarinen, P., Crittenden, R., Mogensen, G., Fondén, R., \& Saarela, M. (2002). Technological challenges for future probiotic foods. International Dairy Journal, 12, 173-182.

Minekus, M., Alminger, M., Alvito, P., Ballance, S., Bohn, T., Bourlieu, C., ... Dufour, C. (2014). A standardised static in vitro digestion method suitable for food - an international consensus. Food \& Function, 5, 1113-1124.

Miranda-Molina, A., Castillo, E., \& Lopez Munguia, A. (2017). A novel two-step enzymatic synthesis of blastose, a $\beta$-D-fructofuranosyl- $(2 \leftrightarrow 6)$-D-glucopyranose sucrose analogue. Food Chemistry, 227, 202-210.

Nascimento, A. K. C., Nobre, C., Cavalcanti, M. T. H., Teixeira, J. A., \& Porto, A. L. F. (2016). Screening of fungi from the genus Penicillium for production of $\beta$ - fructofuranosidase and enzymatic synthesis of fructooligosaccharides. Journal of Molecular Catalysis B: Enzymatic, 134, 70-78.

Nobre, C., Alves Filho, E. G., Fernandes, F. A. N., Brito, E. S., Rodrigues, S., Teixeira, J. A., \& Rodrigues, L. R. (2018). Production of fructo-oligosaccharides by Aspergillus ibericus and their chemical characterization. LWT - Food Science and Technology, 89, 58-64.

Nobre, C., Castro, C. C., Hantson, A. L., Teixeira, J. A., De Weireld, G., \& Rodrigues, L. R. (2016). Strategies for the production of high-content fructo-oligosaccharides through the removal of small saccharides by co-culture or successive fermentation with yeast. Carbohydrate Polymers, 136, 274-281.
Nobre, C., Cerqueira, M.Â., Rodrigues, L. R., Vicente, A. A., \& Teixeira, J. A. (2015). Production and extraction of polysaccharides and oligosaccharides and their use as new food additives. In A. Pandey, R. Hofer, C. Larroche, M. Taherzadeh, \& M Nampoothiri (Eds.). Industrial Biorefineries \& White Biotechnology (pp. 653-679). Amsterdam: Elsevier.

Nobre, C., Teixeira, J. A., \& Rodrigues, L. R. (2012). Fructo-oligosaccharides purification from a fermentative broth using an activated charcoal column. New Biotechnology, 29, 395-401.

Nobre, C., Teixeira, J. A., \& Rodrigues, L. R. (2015). New trends and technological challenges in the industrial production and purification of fructo-oligosaccharides. Critical Reviews in Food Science and Nutrition, 55, 1444-1455.

Padma, S. I., \& Prabhasankar, P. (2014). Prebiotics: Application in bakery and pasta products. Critical Reviews in Food Science and Nutrition, 54, 511-522.

Panesar, P. S., Kumari, S., \& Panesar, R. (2013). Biotechnological approaches for the production of prebiotics and their potential applications. Critical Reviews in Biotechnology, 33, 345-364.

Pool-Zobel, B. L. (2005). Inulin-type fructans and reduction in colon cancer risk: Review of experimental and human data. British Journal of Nutrition, 93(SUPP), S73-S90.

Rada, V., Nevoral, J., Trojanova, I., Tomankova, E., Smehilova, M., \& Killer, J. (2008). Growth of infant faecal bifidobacteria and clostridia on prebiotic oligosaccharides in vitro conditions. Anaerobe, 14, 205-208.

Roberfroid, M. (2007). Prebiotics: The concept revisited. Journal of Nutrition, 137, 830S-837S.

Sangeetha, P. T., Ramesh, M. N., \& Prapulla, S. G. (2005). Maximization of fructooligosaccharide production by two stage continuous process and its scale up. Journal of Food Engineering, 68, 57-64.

Santos-Moriano, P., Fernandez-Arrojo, L., Poveda, A., Jimenez-Barbero, J., Ballesteros, A. O., \& Plou, F. J. (2015). Levan versus fructooligosaccharide synthesis using the levansucrase from Zymomonas mobilis: Effect of reaction conditions. Journal of Molecular Catalysis B: Enzymatic, 119, 18-25.

Shoaf, K., Mulvey, G. L., Armstrong, G. D., \& Hutkins, R. W. (2006). Prebiotic galactooligosaccharides reduce adherence of enteropathogenic Escherichia coli to tissue culture cells. Infection and Immunity, 74, 6920-6928.

Simões, J., Nunes, F. M., Domingues, M. R., \& Coimbra, M. A. (2011). Demonstration of the presence of acetylation and arabinose branching as structural features of locust bean gum galactomannans. Carbohydrate Polymers, 86, 1476-1483.

Su, P., Henriksson, A., \& Mitchell, H. (2007). Selected prebiotics support the growth of probiotic mono-cultures in vitro. Anaerobe, 13, 134-139.

Suzuki, Y., Tanaka, K., Amano, T., Asakura, T., \& Muramatsu, N. (2004). Utilization by intestinal bacteria and digestibility of arabino-oligosaccharides In Vitro. Journal of the Japanese Society for Horticultural Science, 73, 574-579.

Whelan, K., Efthymiou, L., Judd, P. A., Preedy, V. R., \& Taylor, M. A. (2006). Appetite during consumption of enteral formula as a sole source of nutrition: The effect of supplementing pea-fibre and fructo-oligosaccharides. The British Journal of Nutrition, 96(2), 350-356.

Yasuda, H., Shitoh, T., Yamano, T., Itoh, Y., \& Shimura, S. (1986). Identification of neokestose produced from sucrose by an enzyme of Penicillium oxalicum. Agricultural and Biological Chemistry, 50, 777-778. 